\title{
Allelopathic EfFects of Eucalyptus citriodora on AMARYLlis AND Associated GRAsSY WeED ${ }^{1}$
}

\author{
Efeitos Alelopáticos do Eucalyptus citriodora sobre Amarílis e em Gramíneas Daninhas \\ Associadas
}

\author{
EL-ROKIEK, K.G. ${ }^{2}$ and EID, R.A. ${ }^{3}$
}

\begin{abstract}
A Petri dish assay was carried out for screening different concentrations of aqueous extracts of fresh and dry leaves of Eucalyptus citriodora on germination and seedling growth of wild oat weed (Avena fatua). Seed germination, root and shoot length of wild oat exhibited different degrees of inhibition according to the concentration of the aqueous extract. Maximum inhibitions of germination percentage, root and shoot length were recorded when using $25 \%$ fresh leaf extract. Based on this preliminary work (Petri dish assay), studies were conducted under greenhouse conditions at the National Research Center, Egypt, in the two winter seasons of 2006/2007 and 2007/2008 to evaluate the effects of foliar and soil treatments of aqueous extracts of Eucalyptus citriodora fresh and dry leaves on wild oat weed as well as on the growth and flowering of amaryllis (Hippeastrum hybridum), compared with the recommended dose of the herbicide tralkoxydim. Amaryllis fresh and dry weights as well as flowering increased significantly when treated with the previous extracts, especially the fresh leaf extract. However, the fresh and dry weights of wild oat were significantly reduced by the aqueous extracts, either fresh or dry, indicating phytotoxic effects. Tralkoxydim caused complete inhibition of wild oat as compared with the control. The studies involved estimation of the endogenous contents of total phenols in weed. With all the treatments, the inhibitory effects on weeds were correlated with accumulation of the internal contents of total phenols, compared to their respective controls. The amount of phenols correlated well with the weed's growth performance. This study establishes the effect of the aqueous extracts on the weed wild oat, associated with amaryllis, which may serve as a tool in establishing their herbicidal potential.
\end{abstract}

Keywords: aqueous extract, herbicide, phytotoxic, total phenols, tralkoxydim.

\begin{abstract}
RESUMO - Um experimento em placas de Petri foi realizado para a seleção de diferentes concentrações de extratos aquosos de folhas frescas e secas de Eucalyptus citriodora na germinação e no crescimento inicial de aveia-selvagem (Avena fatua). A germinação da semente, a raiz e o comprimento da brotação apresentaram diferentes graus de inibição, de acordo com a concentração do extrato aquoso. As maiores porcentagens de inibição da germinação, de raiz e de comprimento de brotação foram registradas com extrato fresco das folhas a 25\%. Com base no trabalho preliminar (experimento em placa de Petri), foram conduzidos estudos na estufa do Centro de Pesquisa Nacional, Egito, em duas estações de inverno: 2006/2007 e 2007/2008. Nesse local, foram avaliados os efeitos de tratamentos foliar e do solo de extratos aquosos das folhas frescas e secas de Eucalyptus citriodora na aveia-selvagem, assim como no crescimento e no florescimento da espécie Hippeastrum hybridum, em comparação com a dose recomendada do herbicida tralkoxydim. Os pesos frescos e secos do amarilis sofreram aumento significativo, bem como o florescimento, quando tratados com os extratos, principalmente com a pulverização do extrato das folhas frescas. Entretanto, os pesos frescos e secos da aveia-selvagem foram reduzidos significativamente pelos extratos aquosos, tanto frescos como secos, indicando intoxicação. O herbicida tralkoxydim causou a inibição completa de
\end{abstract}

Recebido para publicação em 2.10.2008 e na forma revisada em 11.12.2009.

2 Botany Dept, National Research Centre, Dokki, Cairo, Egypt; ${ }^{3}$ Ornamental Plant and Woody Trees Dept., National Research Centre, Dokki, Cairo, Egypt, <ahmed_ezat2000@yahoo.com>, El Buhoth St.., Dokki, cairo, Egypt. Postal Code: 12311; Tel: (+202) 33371362 /433/615/933/449; $\operatorname{Fax}(+202) 33370931$ 
aveia-selvagem em comparação ao controle. Os estudos envolveram a avaliação dos índices endógenos de fenóis totais na espécie daninha. Em todos os tratamentos, os efeitos inibitórios nas espécies daninhas foram correlacionados com o acúmulo de indices internos dos fenóis totais, comparados aos respectivos controles. Constatou-se boa correlação entre a quantidade de fenóis e o desempenho do crescimento na espécie daninha. Este estudo estabeleceu o efeito dos extratos aquosos sobre a espécie daninha aveia-selvagem associada ao amarílis, o que pode servir como ferramenta para estabelecer seu potencial herbicida.

Palavras-chave: extrato aquoso, herbicida, fitotóxico, fenóis totais, tralkoxydim.

\section{INTRODUCTION}

Amaryllis (Hippeastrum hybridum) is an ornamental bulbous flowering plant of the family Amaryllidaceae. It has large and showy flowers with many bright colors (Jana, 1995) and it is one of the most brilliantly colored spring bulbs. It is suitable for planting in pots, greenhouses, gardens and landscaping. It can be grown under diverse environmental conditions, ranging from tropical to subtropical or temperate climate (Okubo, 1993; Jana, 1995).

Amaryllis has long been a holiday favorite, providing a splash of Christmas red color in mid winter (not in tropical conditions such as those found in Brazil in mid December). This plant will be shipped as a spiking bulb to encourage the beautiful blooming to occur.

Several taxa are used for medicinal, flavoring, psychotropic and other purposes (Meerow et al., 2000).

Weeds are one of the major constraints to plant production worldwide. Weeds affect plant growth and production that may be reduced significantly when weeds compete with them for light, water and minerals (Hussein, 2001). Many important weed problems are similar among the crops because of crop rotation. Thus, lack of adequate nutrition may result in poor flowering, regardless of bulb size.

Increasing herbicide use worldwide is related to several regional factors, primarily increasing labor cost and herbicide availability and efficacy. Because of their environmental and toxicological effects, besides increasing herbicidal resistance among weeds, more alternative strategies against weeds must be developed. This is true and valid for all crops and economic plants grown in the worldwide, such as amaryllis. Thus, efforts are being made to create new environmentallyfriendly means of weed management. Using allelopathy for weed management leads to improved water quality and reduced environmental contamination. Allelopathy is understood as the effect of chemical interactions between plants (Muller, 1969; Gross, 1999). Rice (1984) and Lambers et al. (1998) defined allelopathy as the effect(s) of one plant on other plants through the release of chemical compounds in the environment. Chemical identification procedures have recently become more advanced, and biologically active substances with phytotoxic potential, that can explain allelopathic behaviour, have been found (Duke et al., 1998). The chemicals causing the allelopathic effects are called allelochemicals.

Natural plant products known for their structural and chemical diversity offer a challenging new area for the discovery of new herbicides. Essential oils from a number of higher plants are known to possess greater toxicity and are responsible for allelopathic activity. Thus, volatile oils from Eucalyptus citriodora were selected, based on their known pesticidal and phytotoxic properties.

Previous studies have shown that various Eucalyptus species can yield allelopathic chemicals which may be effective in suppressing understorey vegetation. Allelopathy is associated with Eucalyptus spp. due to the presence of allelochemicals in these plants; several studies have demonstrated the release of phenolic and volatile compounds in its foliage (A1-Naib and Al-Mousawi, 1976). Eucalyptus reduces the growth of neighboring crops through the release of allelochemicals (May and Ash, 1990). The extracts of fresh leaves were found to be most toxic (Al-Naib and 
A1-Mousawi, 1976). It was concluded that allelopathy is likely to be a cause of understorey suppression by Eucalyptus species, especially in drier climates (May and Ash, 1990). Cao and Luo (1996) reported that aqueous extract from bark and leaf, and volatiles from leaves of Eucalytus citriodora showed allelopathic effect on the growth of nine species, including the weeds Bidens pilosa, Digitarie pertenuis, Eragrostics cilianesis, Setaria geniculata, and crops such as corn, rice, cucumber, bean and Stylosanthes guianensi. Studies were carried out to explore the effect of volatile oils from E. citriodora against weeds such as Phalaris minor, Chenopodium album, Echinochloa crus-galli, Ageratum conyzoides, Parthenium hysterophorus, and Amaranthus spp. In laboratory bioassay germination, seedling length, chlorophyll content and respiratory ability of weed plants was drastically affected (Batish et al., 2005).

Therefore, this study aimed to evaluate the effect of $E$. citriodora aqueous extract against the grassy weed wild oat (Avena fatua), associated to amaryllis plants, in comparison to the herbicide tralkoxydim and the reversal of this control on amaryllis (Hippeastrum hybridum) growth and flowering .

\section{MATERIALS AND METHODS}

\section{Laboratory test}

Eucalyptus citriodora plants were gathered from Egyptian gardens. A total of 2.5, 5, 10, 20 or $25 \mathrm{~g}$ of fresh Eucalyptus citriodora leaves were washed with tap water followed by distilled water to remove dust, and transferred into labeled bottles, to which $100 \mathrm{~mL}$ of sterile, deionized, distilled water was added. The mixture was shaken well by hand and allowed to soak for $48 \mathrm{~h}$ at room temperature and filtered to obtain Eucalyptus extracts at 2.5, 5, 10,20 and $25 \%$ concentrations. The same weight of the previous fresh leaves was ovendried at $40^{\circ} \mathrm{C}$ to obtain the corresponding dry weight, ground into a fine powder (using an electric mill until homogeneity was achieved) and transferred into labeled bottles to which $100 \mathrm{~mL}$ of sterile, deionized distilled water was added for 48 hours. The produced extracts were collected and filtered through Whatman no. 1 filter paper. A Petri dish assay was carried out for screening the effect of different concentrations of aqueous extracts of Eucalyptus citriodora on germination and seedling growth of wild oat weed.

Seeds of wild oat were germinated in Petri dishes containing 1-layer Whatman no. 3 filter paper with $6 \mathrm{~mL}$ at different concentrations of $E$. citriodora fresh and dry leaf aqueous extracts, as follows:

a- Fresh leaf extract at 2.5, 5, 10, 15, 20 and $25 \%$.

b- Dry leaf extract at $0.875 \%, 1.570 \%, 3.134 \%$, $4.702 \%, 6.270 \%$ and $7.850 \%$.

c- Untreated control (distilled water).

Germination was carried out in the laboratory in November at average maximum and minimum temperatures $25.5 \pm 1$ and $18.5 \pm 1{ }^{\circ} \mathrm{C}$. The experiment was repeated twice with one week interval. Each treatment was represented by five replicates, with each Petri dish representing one replicate. After five days, $2 \mathrm{~mL}$ of the previous treatments were added. Germination percentage, root and shoot length of wild oat seedlings were recorded 10 days after germination.

\section{Pot experiments}

Pot experiments were conducted under greenhouse conditions at the National Research Center, Dokki, Cairo, Egypt, during two successive winter seasons(2006/2007 and 2007/2008). Amaryllis plant cv. Belinda bulbs were collected from the Agricultural Research Center, Ministry of Agriculture, Giza, Egypt. The bulbs were grown in $30 \mathrm{~cm}$ diameter pots, filled with a soil mixture at average maximum and minimum temperatures of $25.5 \pm 1$ and $18.5 \pm 1{ }^{\circ} \mathrm{C}$. The physical and chemical characteristics of the soil mixture used for growing the bulbs are shown in Table 1 . The pots were infested with wild oat seeds at the rate of 10 seeds per pot. Weed seeds were sown simultaneously and mixed thoroughly at $2 \mathrm{~cm}$ depth from the soil. Routine fertilizers were added as calcium super phosphate $(15.5 \%$ $\mathrm{P}_{2} \mathrm{O}_{5}$ ) before planting at the rate of $3 \mathrm{~g}$ per pot, representing sources of $P$, ammonium sulfate $(20 \% \mathrm{~N})$ at the rate of $2 \mathrm{~g}$ per pot and potassium sulphate $\left(48 \%, \mathrm{~K}_{2} \mathrm{O}\right)$ at the rate of 1 per pot, representing sources of $\mathrm{N}$ and $\mathrm{K}$, respectively, were added 30 days after bulb planting. 
Table 1 - Physical and chemical analyses of the soil

\begin{tabular}{|l|l|c|}
\hline \multicolumn{2}{|c|}{ Character } & Value \\
\hline \multirow{4}{*}{ Physical } & Clay & $22.80 \%$ \\
\cline { 2 - 3 } & Silt & $19.00 \%$ \\
\cline { 2 - 3 } & Sand & $58.22 \%$ \\
\cline { 2 - 3 } & Texture & Sandy clay loam \\
\hline \multirow{5}{*}{ Chemical } & $\mathrm{pH}(\mathrm{SB})$ & 7.63 \\
\cline { 2 - 3 } & Total nitrogen & - \\
\cline { 2 - 3 } & Available P & $35 \mathrm{mg} \mathrm{kg}^{-1}$ soil \\
\cline { 2 - 3 } & Available $\mathrm{K}$ & $8 \mathrm{mg} \mathrm{kg}^{-1}$ soil \\
\cline { 2 - 3 } & Fe & $18.00 \mathrm{mg} \mathrm{kg}^{-1}$ soil \\
\cline { 2 - 3 } & $\mathrm{Mn}$ & $3.21 \mathrm{mg} \mathrm{kg}^{-1}$ soil \\
\cline { 2 - 3 } & Zn & $9.21 \mathrm{mg} \mathrm{kg}^{-1}$ soil \\
\cline { 2 - 3 } & $\mathrm{Cu}$ & $1.30 \mathrm{mg} \mathrm{kg}^{-1}$ soil \\
\cline { 2 - 3 } & Organic matter $\%$ & 2.15 \\
\hline \multirow{5}{*}{ EC $(\mathrm{dS} \mathrm{m})$} & 2.38 \\
\hline
\end{tabular}

3-Alkoxydim treatment (Grasp) at $500 \mathrm{ppm}$, Grasp [tralkoxydim, $10 \%$ Zeneca-England] with molecular formula: 2-[1-(ethoxyimino) propyl]-3-hydroxy-5-mesityl cyclohex-2-enone. 4-Weed-free.

5-Unweeded.

Based on the preliminary work (Petri dish assay), the fresh leaf extract was used at concentrations of 12.5 and $25 \%$ and the corresponding dry leaf extract, as follows:

\section{Preparation of the extract}

Two hundred fifty and $500 \mathrm{~g}$ of fresh leaves of Eucalyptus citriodora were washed with tap water, followed by distilled water to remove dust. Leaves were transferred to labeled beakers, to which $2000 \mathrm{~mL}$ distilled water were added and allowed to soak for 48 hours. The produced extracts were collected and filtered through very fine $(1 \mathrm{~mm})$ mesh and pressed for complete extraction. This step was repeated with the corresponding finely ground dry leaves (oven dried at $40{ }^{\circ} \mathrm{C}$ ), and repeated according to the quantity of extract needed.

The extracts were applied early in the morning 30 days after sowing. The treatments were carried out weekly thrice, as follows:

\section{Spraying treatments}

The following aqueous extracts were applied at the rate of $250 \mathrm{~mL}$ per pot.
1- Aqueous extract of fresh leaves at $12.5 \%$ and $25 \%$.

2- Aqueous extract of dry leaves at $2.9 \%$ and $6.2 \%$.

\section{Soil treatments}

The previous aqueous extracts were applied in the soil at the rate of $250 \mathrm{~mL} \mathrm{~kg}^{-1}$ soil.

1- Aqueous extract of fresh leaves at $12.5 \%$ and $25 \%$.

2- Aqueous extract of dry leaves at $2.9 \%$ and $6.2 \%$.

The pots were arranged in a complete block design with 11 treatments. Each treatment was represented by 9 pots (replicates 1 pot $=$ 1 replicate). The infested weed was collected from each pot at 30 and 60 days after treatments.

Data on amaryllis were recorded for each individual plant at the flowering stage, including leaf length, number of leaves, fresh and dry weight of leaves, flowering date, flower stalk length, stalk diameter, flower diameter, fresh and dry weight of cut spike, fresh weight of bulbs, number of flowers/spike, and number of bulblets.

\section{Determination of essential oil in Eucalyptus citriodora leaves}

The essential oil was prepared by hydrodistillation (Adams, 1995): A known weight (50-70 g) of fresh leaves of Eucalyptus citriodora is subjected to hydro-distillation for 5-6 hours using Clevenger type apparatus for oils lighter than water. The oil yielded was dried over anhydrous sodium sulphate and stored in sealed vials at low temperature before analysis.

GC/MS analysis was carried out on Finningan Mat SSQ7000 mass spectrometer directly coupled to a Varian $3400 \mathrm{GC} / \mathrm{MS}$ system, equipped with a DB-9 fused silica capillary column $(30 \mathrm{~m} \times 0.25 \mathrm{~mm}$ i.d) using helium as the carrier gas with a linear velocity of $31.5 \mathrm{~cm} \mathrm{~s}^{-1}$, split ratio $1 / 60$, ionization energy $70 \mathrm{ev}$, scan time 1 sec., transfer line temp. $260^{\circ} \mathrm{C}$, oven temperature programed, 
$40{ }^{\circ} \mathrm{C}$ to $250{ }^{\circ} \mathrm{C}$ at $4{ }^{\circ} \mathrm{C} \mathrm{min}^{-1}$. The percentages of compounds were calculated by the area normalization method without considering response factors. The oil components were identified by comparing their mass spectra with authentic compounds. Oven dried leaves $\left(\right.$ at $40^{\circ} \mathrm{C}$ ) were subjected to the same previous analysis.

\section{Determination of chemical changes in weeds}

\section{Total phenols in wild oat weed}

Total phenolic compounds in oat weed were extracted from drying finely ground tissues (powdered). Drying was carried out in an electric oven at $60{ }^{\circ} \mathrm{C}$ until constant weight was achieved. Total phenols were determined colorimetrically according to the method defined by Snell and Snell (1953), using Folin and Ciocalteu phenol reagent.

\section{A-Photosynthetic pigments in amaryllis}

Chlorophylls a, b and carotenoids were extracted from fresh leaves and estimated, according to colorimetrically Wettstein method (1957).

\section{B- Total carbohydrate contents}

Total carbohydrate contents were extracted from drying finely ground tissues (powdered). Drying was carried out in an electric oven at $60{ }^{\circ} \mathrm{C}$, until constant weight was achieved. Total carbohydrates were extracted according to Herbert et al. (1971) and estimated colorimetrically by the phenolsulphoric acid method, as described by Montogomery (1961).

\section{C- Nitrogen, phosphorus and potassium contents (NPK)}

Nitrogen, phosphorus and potassium contents were determined in dried organs according to the official and modified methods of analysis (AOAC, 1984).

Statistical analysis: The data obtained were submitted to standard analysis of variance; the LSD values were obtained when $F$ values were significant at 5\% level (Snedecor \& Cochran, 1980).

\section{RESULTS AND DISCUSSION}

Most allelopathy research is focused on direct negative plant-plant interactions caused by allelochemicals. Therefore, understanding plant interactions is important to reduce the dependency on herbicide in future cropping systems. Allelopathy plays an important role in plant interaction in some plant species (Olofsdotter et al., 2002).

Table 2 data show that the germination percentage of wild oat seeds is negatively affected by fresh and dry leaf extract of E. citriodora at different concentrations, compared to untreated control. Table 2 shows that fresh leaf extract was more effective. Maximum inhibition was recorded by spraying $25 \%$ fresh leaf extract when the percentage of germination reached $35 \%$. Various laboratory screening techniques have been developed to demonstrate measure and quantify allelopathy without the interference of resource competition (Navarez and Olofsdotter 1996; Kawaguchi et al., 1997). The results also show that root and shoot seedlings of wild oat were significantly reduced by the different aqueous extracts. This inhibition was observable by spraying $25 \%$ fresh leaf extract $(81.5 \%)$. It is clear that shoots were less sensitive than

Table 2 - Effect of different aqueous extracts of fresh and dry leaves of Eucalyptus citriodora on seedling root and shoot length of wild oat weed

\begin{tabular}{|l|c|c|c|c|}
\hline \multirow{2}{*}{ Treatment (\%) } & \multicolumn{3}{|c|}{ Wild oat seedling } \\
\cline { 3 - 5 } \multicolumn{1}{|c|}{} & $\begin{array}{c}\text { Germination } \\
(\%)\end{array}$ & $\begin{array}{c}\text { Root length } \\
(\mathrm{cm})\end{array}$ & $\begin{array}{c}\text { Shoot length } \\
(\mathrm{cm})\end{array}$ \\
\hline \multirow{4}{*}{$\begin{array}{l}\text { Fresh leaf } \\
\text { extract }\end{array}$} & 2.50 & 100.0 & 7.50 & 11.44 \\
\cline { 2 - 5 } & 5.00 & 84.4 & 5.64 & 9.56 \\
\cline { 2 - 5 } & 10.00 & 75.2 & 5.26 & 9.10 \\
\cline { 2 - 5 } & 15.00 & 75.8 & 4.50 & 8.04 \\
\cline { 2 - 5 } & 20.00 & 67.6 & 4.10 & 7.10 \\
\cline { 2 - 5 } & 25.00 & 34.9 & 2.44 & 5.56 \\
\hline \multirow{4}{*}{$\begin{array}{l}\text { Dry leaf } \\
\text { extract }\end{array}$} & 0.85 & 100.0 & 11.80 & 12.10 \\
\cline { 2 - 5 } & 1.75 & 82.5 & 11.28 & 12.06 \\
\cline { 2 - 5 } & 3.26 & 80.6 & 10.10 & 11.16 \\
\cline { 2 - 5 } & 4.70 & 70.0 & 9.24 & 9.36 \\
\cline { 2 - 5 } & 6.26 & 68.8 & 9.12 & 8.32 \\
\cline { 2 - 5 } & 7.85 & 54.6 & 8.24 & 7.46 \\
\hline Control & 0.0 & 100.0 & 13.18 & 12.54 \\
\hline \multirow{2}{*}{ LSD } & at 5\% & 2.42 & 0.52 & 0.56 \\
\hline \multirow{2}{*}{ at $1 \%$} & 3.42 & 0.74 & 0.81 \\
\hline
\end{tabular}


roots (Table 2). Remarkable inhibition in seedling shoot length reached $55.7 \%$ with the same treatment.

\section{Pot experiments}

\section{Weeds}

Results show that both fresh and dry weights of wild oat weed were significantly reduced by applying the herbicide tralkoxydim or different extracts of E. citriodora 30 and 60 days after sowing (Table 3 ). These results were true with different applications. The reduction caused by the herbicide was higher. The highest reduction in fresh weight caused by the extracts was observed when $25 \%$ of fresh leaf extract of $E$. citriodora was sprayed, which amounted to 79.6 and $59.8 \%, 30$ and 60 days after sowing, respectively. The dry weight reduction exhibited similar trend at both stages.

Aqueous extracts of different species of Eucalyptus were documented by several authors (A1-Naib and Al-Mousawi, 1976; May and Ash, 1990; Cao and Luo 1996). The results obtained with $E$. citriodora leaf extracts were in agreement with previous studies (Nishirnura et al., 1982; Florentine and Fox, 2003; Batish et al., 2005). In general, reduced growth of many weed species in response to different plant extracts is well reported
(Rice, 1984; Olofsdotter et al., 2002, Cheema et al., 2003; E1-Rokiek et al., 2006). High weed growth suppression may be attributed to the presence of toxin compounds in the aqueous extracts, as reported by many authors (Barnes and Putnam, 1986; May and Ash, 1990; Shilling et al., 1992 and Shiming, 2005). These compounds are volatile oils and phenolic acids (Bignell et al., 1994 and Lisanework et al., 1993). Data in Table 8 may support these results. The herbicide caused complete inhibition of this weed. Similar results were reported by (Singh et al., 1995; Fayed et al., 1998).

\section{Changes in phenolic contents in wild oat weed}

Table 4 results show that great differences were found between the total phenol contents in weed treated with different extracts of E. citriodora and those in untreated weed. Generally, foliar treatment application resulted in relatively higher contents than soil treatment application. The results also indicated that accumulation of total phenols correlated with extract concentration. Accumulation of total phenols in wild oat dried tissues was observed after spraying $25 \%$ of fresh leaf extract, at both growth stages, compared to the corresponding controls. Accumulation of phenols is often a

Table 3 - Effect of different aqueous extracts of fresh and dry leaves of Eucalyptus citriodora on growth of wild oat weed (Average of the two seasons)

\begin{tabular}{|c|c|c|c|c|c|c|}
\hline & \multirow{3}{*}{ Treatment $(\%)$} & & \multicolumn{2}{|c|}{ FW (g per pot) } & \multicolumn{2}{|c|}{ DW (g per pot) } \\
\hline & & & \multicolumn{4}{|c|}{ DAS (Days after sowing) } \\
\hline & & & 60 & 90 & 60 & 90 \\
\hline \multirow{4}{*}{ Spraying } & \multirow{2}{*}{ Fresh leaf extract } & 12.5 & 4.40 & 10.47 & 0.569 & 2.432 \\
\hline & & 25.0 & 2.02 & 6.42 & 0.471 & 1.375 \\
\hline & \multirow{2}{*}{ Dry leaf extract } & 2.9 & 6.35 & 11.67 & 1.120 & 2.668 \\
\hline & & 6.2 & 3.22 & 7.58 & 0.526 & 1.422 \\
\hline \multirow{4}{*}{$\begin{array}{l}\text { Soil } \\
\text { treatment }\end{array}$} & \multirow{2}{*}{ Fresh leaf extract } & 12.5 & 4.98 & 13.89 & 0.952 & 3.691 \\
\hline & & 25.0 & 3.23 & 8.68 & 0.503 & 1.741 \\
\hline & \multirow{2}{*}{ Dry leaf extract } & 2.9 & 7.20 & 14.25 & 0.986 & 3.762 \\
\hline & & 6.2 & 4.03 & 10.02 & 0.800 & 2.138 \\
\hline Herbicide & Tralkoxydim & $500 \mathrm{ppm}$ & - & - & - & - \\
\hline Weed-free & - & - & - & - & - & - \\
\hline Unweeded & - & - & 9.9 & 15.99 & 1.658 & 3.906 \\
\hline \multicolumn{3}{|c|}{ L.S.D. at $5 \%$} & 0.37 & 0.65 & 0.041 & 0.045 \\
\hline
\end{tabular}


characteristic of stress condition (Nemat Alla and Younis, 1995; Ahmed and Rashad, 1996; Hopkins, 1999; El-Rokiek, 2002 and 2007).

\section{Amaryllis growth}

Leaf length and number of leaves of amaryllis plants at the flowering stage were significantly increased by all the applied extracts as well as by the herbicide tralkoxydim, compared to the unweeded control (Table 5). Spraying treatments produced relatively higher results than soil treatments. Maximum leaf length increase was obtained with weed-free and herbicide treatment followed by spraying treatment of fresh leaf extract of E. citriodora at $25 \%$. These increments reached $86.5,84.4$ and $69.7 \%$, respectively. In addition, fresh weight of amaryllis leaves seemed to significantly increase in response to all treatments of either fresh or dry leaf application, as well as tralkoxydim. Maximum increase was obtained with weed-free control and herbicide treatment followed by $25 \%$ of fresh leaf extract spray treatment. Fresh weight increase was accompanied by dry matter accumulation (Table 5), compared to the untreated control. In this respect, fresh leaf extract induced the best performance, especially at its highest concentration. On the other hand, growth increase of amaryllis plants treated with different aqueous extracts of E. citriodora leaves or tralkoxydim was accompanied by the

Table 4 - Effect of different aqueous extracts of fresh and dry leaves of Eucalyptus citriodora on total phenol contents in wild oat (Average of the two seasons)

\begin{tabular}{|c|c|c|c|c|}
\hline & \multicolumn{2}{|l|}{ Treatment (\%) } & \multicolumn{2}{|c|}{$\begin{array}{l}\text { Total phenols } \\
\left(\mathrm{mg} \mathrm{g}^{-1} \mathrm{DW}\right)\end{array}$} \\
\hline & & & $60 \mathrm{DAS}$ & $90 \mathrm{DAS}$ \\
\hline \multirow{4}{*}{ Spraying } & \multirow{2}{*}{ Fresh leaf extract } & 12.5 & 50.14 & 33.03 \\
\hline & & 25.0 & 56.29 & 57.28 \\
\hline & \multirow{2}{*}{ Dry leaf extract } & 2.9 & 32.83 & 18.61 \\
\hline & & 6.2 & 52.60 & 34.64 \\
\hline \multirow{4}{*}{$\begin{array}{l}\text { Soil } \\
\text { treatment }\end{array}$} & \multirow{2}{*}{ Fresh leaf extract } & 12.5 & 24.14 & 18.24 \\
\hline & & 25.0 & 34.84 & 21.41 \\
\hline & \multirow{2}{*}{ Dry leaf extract } & 2.9 & 12.66 & 12.62 \\
\hline & & 6.2 & 26.05 & 20.24 \\
\hline Herbicide & Tralkoxydim & $500 \mathrm{ppm}$ & - & - \\
\hline Unweeded & - & - & 12.73 & 9.76 \\
\hline \multicolumn{3}{|c|}{ L.S.D at $5 \%$} & 1.11 & 0.86 \\
\hline
\end{tabular}

corresponding decrease in fresh and dry weight of grassy weed. Many workers reported that controlling weeds associated with plants reduced competition, consequently increasing plant growth (Singh et al., 1995; Fayed et al., 1998; Kumar et al., 2005; E1-Metwally and El-Rokiek, 2007).

\section{Amaryllis flowering}

\section{Days to first flower emergence}

The time required for first flower emergence varied widely (Table 6) with different treatments of E. citriodora leaf extracts. The earliest first flower emergence was obtained with weed-free control (149 days) followed by the tralkoxydim-treated plants (150 days), with the extract treatments exhibiting great variation (from 153 to 163 days) Fresh leaf extract spray at 25\% produced the most rapid flowering (153 days). The maximum time required was observed in unweeded control (164 days), i.e., unweeded control delayed flowering 11 days, compared to the weed-free treatment (from153-to 164 days), with the likely explanation for this being that weed competition reduced amaryllis growth and nutrient uptake and that these may have a role in delaying amaryllis flowering, as reported by Hussein, 2001.

\section{Number of flowers/plant}

The number of flowers per plant showed no significant response by all treatments, as compared to the untreated control (Table 6).

\section{Flower stalk length}

Weed-free control recorded the longest flower stalk $(20.20 \mathrm{~cm})$, followed by the tralkoxydim treatment $(19.7 \mathrm{~cm})$ and the fresh extract spray treatment $(18.9 \mathrm{~cm})$. On the other hand, the shortest flower stalk was obtained in the unweeded control $(15.8 \mathrm{~cm})$, as shown in Table 6.

\section{Flower diameter}

Table 6 data indicate that the different extracts of E. citriodora leaves had a great influence on flower diameter. The largest $(12.7 \mathrm{~cm})$ flower diameter was obtained under 
Table 5 -Effect of different aqueous extracts of fresh and dry leaves of Eucalyptus citriodora on growth of amaryllis (Average of the two seasons)

\begin{tabular}{|c|c|c|c|c|c|c|}
\hline & \multirow{2}{*}{\multicolumn{2}{|c|}{ Treatment $(\%)$}} & \multirow{2}{*}{$\begin{array}{l}\text { Leaf length } \\
(\mathrm{cm})\end{array}$} & \multirow{2}{*}{$\begin{array}{c}\text { Number of } \\
\text { leaves/per plant }\end{array}$} & \multicolumn{2}{|c|}{ Leaves per plant $(\mathrm{g})$} \\
\hline & & & & & FW & DW \\
\hline \multirow{4}{*}{ Spraying } & \multirow{2}{*}{ Fresh leaf extract } & 12.5 & 50.8 & 9.0 & 80.01 & 11.83 \\
\hline & & 25.0 & 55.5 & 14.0 & 83.71 & 12.30 \\
\hline & \multirow{2}{*}{ Dry leaf extract } & 2.9 & 48.3 & 7.0 & 77.91 & 8.61 \\
\hline & & 6.2 & 53.7 & 9.0 & 80.17 & 11.88 \\
\hline \multirow{4}{*}{ Soil treatment } & \multirow{2}{*}{ Fresh leaf extract } & 12.5 & 40.0 & 6.0 & 70.18 & 6.83 \\
\hline & & 25.0 & 48.2 & 6.0 & 77.53 & 8.51 \\
\hline & \multirow{2}{*}{ Dry leaf extract } & 2.9 & 32.9 & 7.0 & 50.31 & 4.94 \\
\hline & & 6.2 & 44.8 & 7.0 & 73.41 & 7.23 \\
\hline Herbicide & Tralkoxydim & $500 \mathrm{ppm}$ & 60.3 & 14.0 & 86.47 & 12.90 \\
\hline Weed-free & - & - & 61.0 & 14.0 & 88.55 & 13.76 \\
\hline Unweeded & - & - & 32.7 & 5.0 & 49.81 & 4.93 \\
\hline \multicolumn{3}{|c|}{ LSD at $5 \%$} & 3.6 & 0.8 & 0.31 & 2.31 \\
\hline
\end{tabular}

Table 6 - Effect of different aqueous extracts of fresh and dry leaves of Eucalyptus citriodora on fresh weight of bulbs, fresh and dry weight of cut spike, flowering characters of amaryllis. (Average of the two seasons)

\begin{tabular}{|c|c|c|c|c|c|c|c|c|c|c|}
\hline \multicolumn{2}{|c|}{ Treatment $(\%)$} & \begin{tabular}{|c|} 
Days \\
to flower \\
bud \\
appearance
\end{tabular} & $\begin{array}{c}\text { Number of } \\
\text { flowers } \\
\text { per plant }\end{array}$ & $\begin{array}{c}\text { Flower } \\
\text { stalk length } \\
(\mathrm{cm})\end{array}$ & $\begin{array}{c}\text { Stalk } \\
\text { diameter } \\
(\mathrm{cm})\end{array}$ & $\begin{array}{c}\text { Flower } \\
\text { diameter } \\
(\mathrm{cm})\end{array}$ & $\begin{array}{l}\text { FW of cut } \\
\text { spike } \\
\text { (g per plant) }\end{array}$ & $\begin{array}{c}\text { DW } \\
\text { of cut spike } \\
\text { (g per plant) }\end{array}$ & $\begin{array}{c}\text { Number of } \\
\text { bulblets } \\
\text { per plant }\end{array}$ & $\begin{array}{l}\text { FW bulbs } \\
\text { (g per plant) }\end{array}$ \\
\hline \multirow{2}{*}{$\begin{array}{l}\text { Fresh leaf } \\
\text { extract }\end{array}$} & 12.5 & 156.5 & 4.0 & 53.43 & 18.03 & 5.12 & 92.00 & 5.52 & 2.14 & 169.50 \\
\hline & 25.0 & 153.0 & 4.0 & 56.21 & 18.91 & 6.10 & 95.56 & 5.82 & 2.32 & 176.40 \\
\hline \multirow{2}{*}{\begin{tabular}{|l|}
$\begin{array}{l}\text { Dry leaf } \\
\text { extract }\end{array}$ \\
\end{tabular}} & 2.9 & 157.0 & 4.0 & 51.45 & 16.41 & 4.81 & 89.83 & 4.23 & 2.00 & 162.43 \\
\hline & 6.2 & 152.0 & 4.0 & 54.81 & 17.51 & 5.77 & 92.43 & 5.58 & 2.14 & 171.80 \\
\hline \multirow{2}{*}{$\begin{array}{l}\text { Fresh leaf } \\
\text { extract }\end{array}$} & 12.5 & 163.5 & 4.0 & 49.70 & 16.41 & 4.80 & 78.41 & 3.54 & 1.87 & 157.22 \\
\hline & 25.0 & 160.0 & 4.0 & 58.00 & 19.50 & 6.82 & 85.30 & 4.10 & 1.89 & 161.58 \\
\hline \multirow{2}{*}{\begin{tabular}{|l|}
$\begin{array}{l}\text { Dry leaf } \\
\text { extract }\end{array}$ \\
\end{tabular}} & 2.9 & 164.0 & 4.0 & 45.63 & 15.89 & 4.35 & 75.62 & 3.23 & 1.77 & 152.50 \\
\hline & 6.2 & 163.5 & 4.0 & 48.90 & 16.40 & 4.80 & 85.00 & 4.00 & 1.89 & 161.58 \\
\hline Tralkoxydim & $500 \mathrm{ppm}$ & 150.0 & 4.0 & 58.30 & 19.73 & 6.80 & 100.00 & 7.83 & 2.51 & 189.51 \\
\hline Weed-free & - & 149.0 & 4.0 & 60.31 & 20.20 & 6.85 & 101.40 & 7.84 & 2.68 & 194.30 \\
\hline Unweeded & - & 164.5 & 4.0 & 43.28 & 15.81 & 4.28 & 73.20 & 2.83 & 1.20 & 152.00 \\
\hline \multicolumn{2}{|c|}{ LSD at $5 \%$} & 0.5 & $\mathrm{NS}$ & 1.51 & 0.08 & 0.05 & 0.73 & 0.02 & 0.04 & 2.31 \\
\hline
\end{tabular}

weed-free control and herbicide treatment, as well as in the fresh leaf extract spray treatments $(6.9,6.8$ and $6.1 \mathrm{~cm}$, respectively). The smallest flower diameter was recorded with unweeded control $(4.3 \mathrm{~cm})$. The stalk diameter results were similar.

\section{Cut spike fresh and dry weights}

A significant increase was observed in cut spike fresh weight in response to the fresh and dry leaf extract and tralkoxydim treatments. The greatest response was found with weedfree control as well as the herbicide. This effect was also true with application of fresh leaf extract at $25 \%$. The pattern of change in dry weight due to these treatments was, to a great extent, similar to that in fresh weight (Table 6).

\section{Number of bulblets per plant}

Number of bulblets per plant differed significantly due to the different extract applications and herbicide treatments (Table 6). The maximum number of bulblets (2.68) was found in weed-free control followed by the herbicide treatment (2.51) and fresh leaf extract spray treatment at $25 \%(2.32)$. The lowest number of bulblets (1.2) per plant was recorded with unweeded control. 


\section{Fresh weight of bulbs (g)}

Table 6 data show that there are great variations in bulb fresh weight due to the application of different extracts of E. citriodora leaves and tralkoxydim, compared to the control. Significant increase was obtained with all treatments. Fresh and dry leaf extracts caused a significant increase. Fresh leaf extract application was superior, with fresh leaf extract spray inducing the best performance, especially at its highest concentration (25\%). The positive effects on amaryllis growth would explain the increased flower net return (Table 6). Previous studies indicated that increased amaryllis growth was accompanied by increasing flowering characters (Bose et al., 1981; Okubo, 1993; Jana, 1995; Siddique et al., 2006 and 2007).

\section{Effect of aqueous extracts of Eucalyptus citriodora on chemical constituents of photosynthetic pigments}

Different treatments of E. citiodora leaf extracts revealed significant increase in chlorophyll a \& b, and carotenoids in fresh leaves of amaryllis over the unweeded control (Table 7). Tralkoxydim generally induced extra increase of chlorophyll a \& b over corresponding levels in the plants treated with extracts. This level was more obvious with weed-free control.
The results of total pigments and carotenoids were similar (Table 7 ).

\section{Total carbohydrate contents}

Table 7 results show that different Eucalyptus leaf extracts caused significant increase in the contents of total carbohydrate in amaryllis leaves. Such increase was more remarkable due to the spray of fresh leaf extract at $25 \%$. The herbicide treatment

Table 8 - Constituents of the essential oil in Eucalyptus citriodora leaves

\begin{tabular}{|l|c|c|}
\hline \multicolumn{1}{|c|}{ Compound (\%) } & Fresh leaves & Dry leaves \\
\hline Citronellal & 61.5 & 56.4 \\
\hline Citronellol & 5.8 & 3.8 \\
\hline Citronellyl acetat & 1.1 & 0.9 \\
\hline$\beta$-caryophellene & 2.4 & 1.7 \\
\hline Isopulegol & 2.3 & 1.3 \\
\hline Neral & 3.9 & 3.5 \\
\hline Borneol & 6.3 & 7.8 \\
\hline Geraniol & 1.1 & - \\
\hline Eugenol & 4.6 & - \\
\hline P-cymene & 2.4 & 2.2 \\
\hline Lemonene & 2.2 & 2.8 \\
\hline Linalool & 2.3 & 5.1 \\
\hline$\alpha$-pinene & 1.9 & 8.2 \\
\hline Terpinene & 1.7 & Traces \\
\hline Unknown & 0.5 & 6.1 \\
\hline
\end{tabular}

Table 7 - Effect of different aqueous extracts of fresh and dry leaves of Eucalyptus citriodora on the contents of chlorophyll a, b, total chlorophyll and carotenoids and total carbohydrate of amaryllis. (Average of the two seasons)

\begin{tabular}{|c|c|c|c|c|c|c|c|c|}
\hline & \multirow{2}{*}{\multicolumn{2}{|c|}{ Treatment (\%) }} & \multicolumn{3}{|c|}{$\begin{array}{l}\text { Total chlorophyll contents } \\
\text { (mg g } \mathrm{m}^{-1} \text { fresh leaves) }\end{array}$} & \multirow{2}{*}{$\begin{array}{l}\text { Carotenoids } \\
\left(\mathrm{mg} \mathrm{g}^{-1} \text { fresh }\right. \\
\text { leaves })\end{array}$} & \multicolumn{2}{|c|}{$\begin{array}{c}\text { Total carbohydrate } \\
\text { contents } \\
\left(\mathrm{mg} \mathrm{g}^{-1} \mathrm{DW}\right)\end{array}$} \\
\hline & & & Chl a & Chl b & Total Chl & & Leaves & Bulbs \\
\hline \multirow{4}{*}{ Spraying } & \multirow{2}{*}{ Fresh leaf extract } & 12.5 & 2.18 & 1.51 & 3.69 & 0.631 & 46.50 & 21.50 \\
\hline & & 25.0 & 2.35 & 1.77 & 4.12 & 0.794 & 48.90 & 23.30 \\
\hline & \multirow{2}{*}{ Dry leaf extract } & 2.9 & 2.09 & 1.47 & 3.56 & 0.630 & 43.20 & 21.50 \\
\hline & & 6.2 & 2.35 & 1.56 & 3.91 & 0.725 & 46.70 & 22.70 \\
\hline \multirow{4}{*}{ Soil treatment } & \multirow{2}{*}{ Fresh leaf extract } & 12.5 & 1.83 & 1.32 & 3.15 & 0.354 & 38.20 & 16.50 \\
\hline & & 25.0 & 2.00 & 1.43 & 3.43 & 0.425 & 40.70 & 18.90 \\
\hline & \multirow{2}{*}{ Dry leaf extract } & 2.9 & 1.35 & 0.89 & 2.24 & 0.350 & 37.80 & 16.50 \\
\hline & & 6.2 & 1.89 & 1.40 & 3.29 & 0.410 & 40.10 & 18.30 \\
\hline Herbicide & Tralkoxydim & $500 \mathrm{ppm}$ & 2.87 & 1.81 & 4.68 & 0.811 & 51.00 & 25.40 \\
\hline Weed-free & - & - & 2.89 & 1.82 & 4.71 & 0.851 & 51.30 & 25.70 \\
\hline Unweeded & - & - & 1.03 & 0.85 & 1.88 & 0.211 & 33.50 & 11.50 \\
\hline \multicolumn{3}{|c|}{ LSD at $5 \%$} & 0.03 & 0.04 & 0.02 & 0.004 & 2.73 & 1.81 \\
\hline
\end{tabular}


was more effective in increasing total carbohydrate, as compared to the control. Total carbohydrate contents in bulbs were greatly affected by the different leaf extract and tralkoxydim treatments. It is evident that E. citriodora extract treatments induced a highly significant enhancement of the total carbohydrates in the plant bulbs. Total carbohydrate content was higher when fresh extract was used, compared to the dry extract.

\section{Nitrogen, phosphorus and potassium contents}

Figures 1 and 2 results indicate that there were significant increases in the contents of $\mathrm{N}, \mathrm{P}$ and $\mathrm{K}$ in both amaryllis leaves and bulbs,

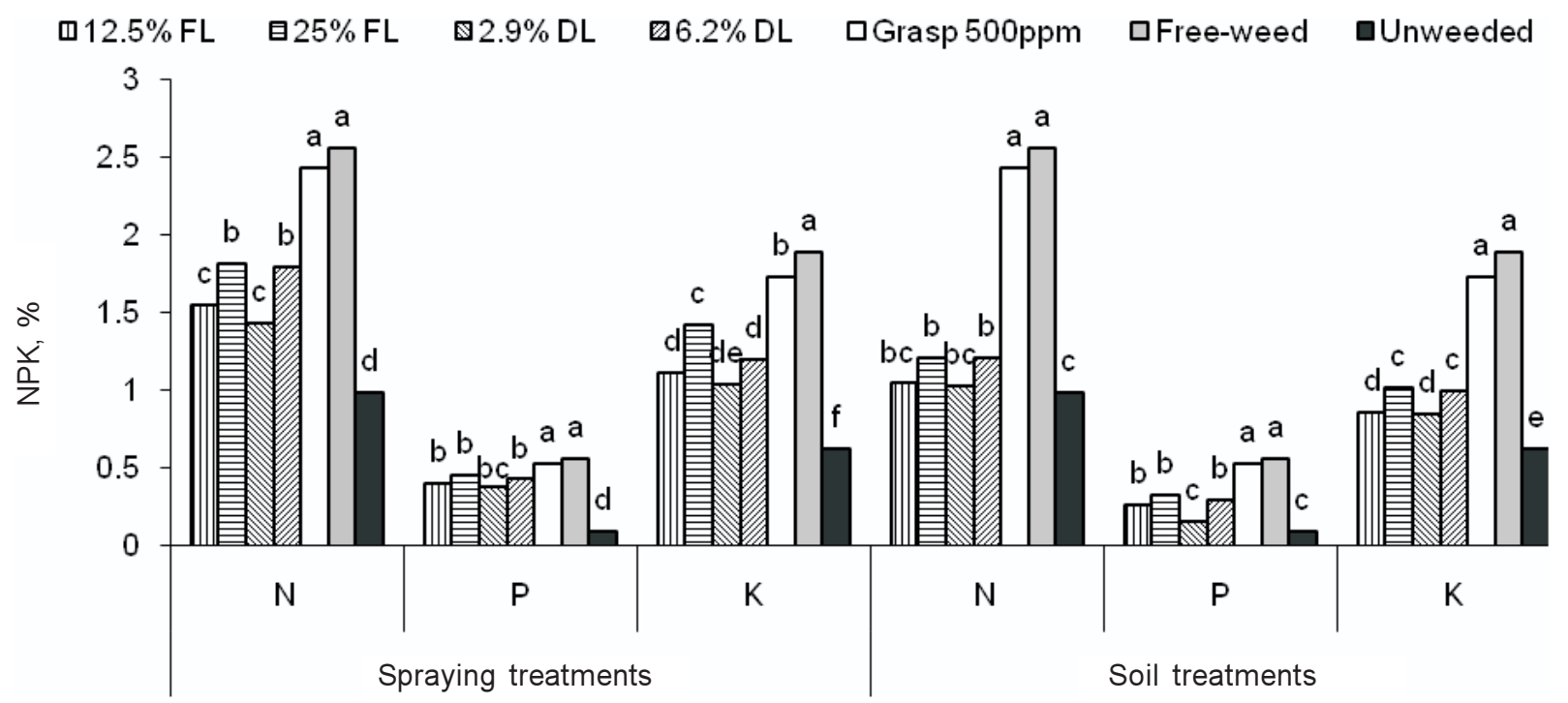

Figure 1 - Effect of different aqueous extracts of fresh and dry leaves of Eucalyptus citriodora on nitrogen, phosphorus and potassium contents of amaryllis leaves.

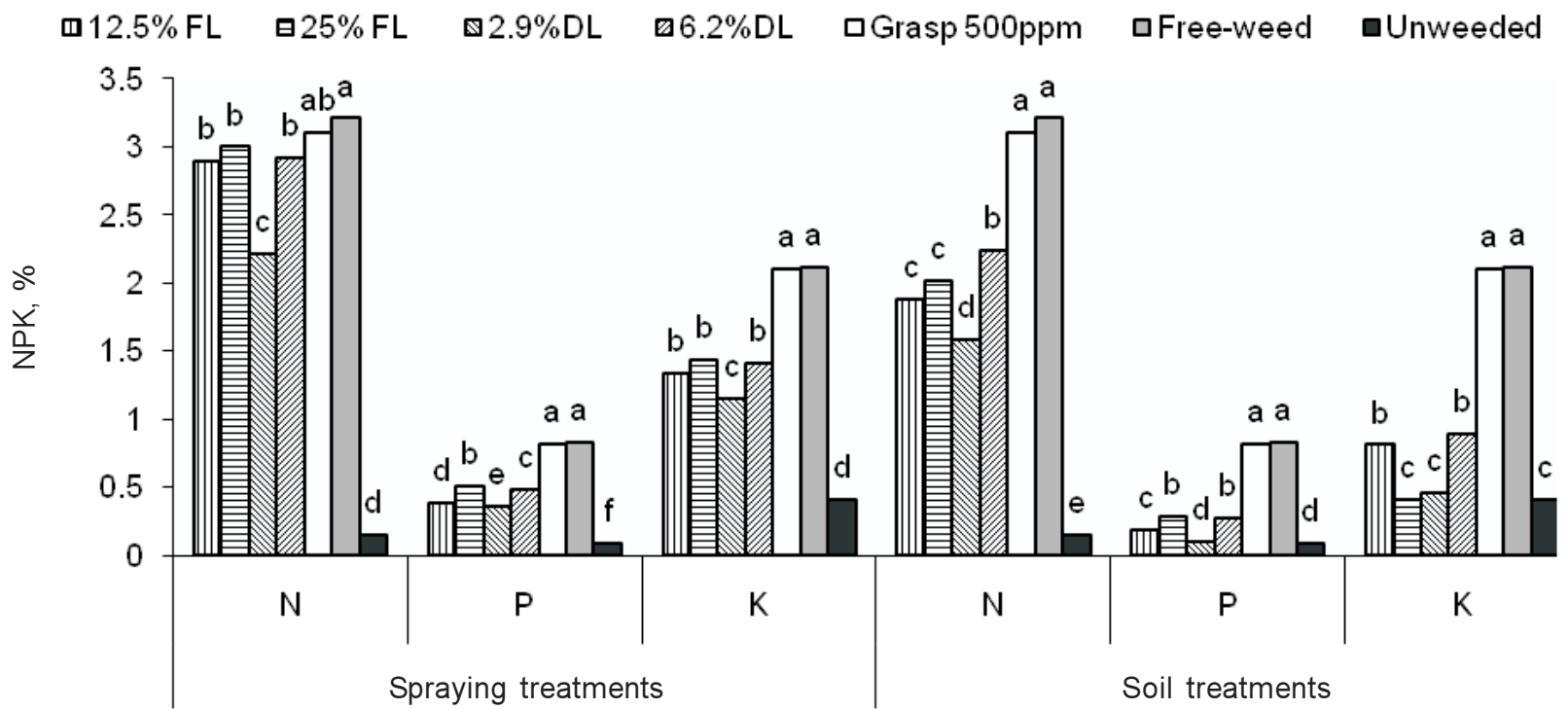

Figure 2 - Effect of different aqueous extracts of fresh and dry leaves of Eucalyptus citriodora on nitrogen, phosphorus and potassium contents of amaryllis bulbs. 
due to the treatments with the different extracts sprayed or soil applied and herbicide. Significant high levels of N, P and K contents in amaryllis leaves were recorded with spraying treatments, especially when the fresh leaf extract was used (Figure 1). The contents of N, $\mathrm{P}$ and $\mathrm{K}$ in amaryllis plant leaves undergoing the weed-free and herbicide treatments surpassed all treatments, compared with the corresponding contents in the unweeded control. In addition, there was a significant increase in the contents of N, P and $\mathrm{K}$ in amaryllis bulbs (Figure 2) with fresh leaf extract spray of $E$. citriodora, which was found to have a better effect, compared to the contents of the corresponding controls. The increase caused by weed-free control and herbicide application was higher.

Increases in different metabolic pathway activities such as chlorophyll synthesis and, consequently, total carbohydrates (Table 7) were concomitant with amaryllis growth. Significant increase in nutrient contents in leaves and bulbs (Figures 1 and 2) of amaryllis plants may be attributed to reduced weed/ plant competition (Hussein, 2001) due to the treatments with the previous extracts.

This work indicated that the leaf extracts of $E$. citriodora have the potential of acting as a natural herbicide against wild oat (Avena fatua) The fresh leaf extract of E. citriodora which contains different volatile oil compounds was more effective than the dry leaf extract. Their effectiveness in controlling weeds may favor their use in agricultural systems, with a concomitant decrease in the need for synthetic herbicides.

\section{ACKNOWLEDGMENT}

The authors thank the Agricultural Research Center in Giza, Cairo, Egypt for providing amaryllis bulbs and help with the chemical analysis, and the Egyptian National Research Center for facilitating this work.

\section{LITERATURE CITED}

ASSOCIATION OF OFFICIAL ANALYTICAL CHEMISTS - AOAC. Official methods of analysis of the Association of Official Analytical Chemists. 21.ed. Washigton D.C., 1984.
ADAMS, R. P. Identification of essential oil components by Gas Chromatography/ Mass Spectroscopy. 4 ed. Carol Stream, IL: Allured Publishing Corporation, 1995.

AHMED, A. H. H.; RASHAD, M. H. Comparative studies on the effect of fusilade in corn (Zea mays) and soybean (Glysine max) plants. Bull. Faculty of Agric. Cairo Univ., v. 47, n. 4 , p. $577-610,1996$

Al-NAIB, F. A. G; Al-MOUSAWI, A. H. Allelopathic effects of Eucalyptus microtheca. Identification and characterization on the phenolic compounds in Eucalyptus microtheca. J. Univ. Kuwit Sci., v. 3, p. 83-87, 1976.

BARNES, J. P; PUTNAM, A. R. Evidence for allelopathy by residues and aqueous extracts of rye (Secale cereale).

Weed Sci., v. 34, p. 384-390, 1986

BATISH, D. R. et al. Herbicidal activity of volatile oils from Eucalyptus citriodora. Second European Allelopathy Symposium"Allelopathy - from understanding to application" 2005., Jul 19. p. 29.

BIGNELL, C. M. et al. Volatile leaf oils of some South Australian species of the genus eucalyptus. Part I: Subgenus symphyomyrtus, section Dumaria, series Incrassatae. Flavour and Fragrance J., v. 9, p. 113-117, 1994.

BOSE, T. K; JANA, B. K; MUKHPADHYAY, T. P. A note on the effect of day length on growth and flowering in Hippeastrum. Indian J. Horti., v. 38, p. 110-112, 1981.

CAO, P. R; LUO, M. S. L. Allelopathy in South China agroecosystems. In: The Fourth World Congress on Allelopathy, Charles Sturt University, Wagga Wagga, NSW, Australia, 21-26 August, 2005, p. 8-10.

CHEEMA, ZA; KHALIQ, A; MUBEEN, M. Response of wheat and winter weeds to foliar application of different plant water extracts of sorghum (S. bicolor). Pak. J. Weed Sci. Res., v. 9, n. 12, p. 89-97, 2003.

DUKE, S.O; DAYAN, F. E; RIMANDO, A. M. Natural products as tools for weed management. Proc. Jpn Weed Sci., Suppl. p. 1-11, 1998.

\section{EL-METWALLY, I. M; EL-ROKIEK KOWTHAR G.} Response of wheat plants and accompanied weeds to some new herbicides alone or combined in sequence. Arab. Univ. J. Agric. Sci., Ain Shams Univ., v. 15, n. 2, p. 513-525, 2007.

EL-ROKIEK KOWTHAR G. Alleviation of the Phytotoxicity of Some Herbicides on Some Economic Crops. 2002. pp 280. Thesis (Doctoral in Plant) - Faculty of Sci. Ain Shams, Univ., Cairo, 2002.

EL-ROKIEK KOWTHAR G.; EL-SHAHAWY, T. A.; SHARARA, F. A. New approach to use rice straw waste for weed control II. The effect of rice straw extract and fusilade (herbicide) on some weeds infesting soybean (Glycin max L.). International journal of Agriculture and Biology, v. 8, n. 2, p. 269-275, 2006. 
EL-ROKIEK KOWTHAR G. Evaluating the physiological influence of benzoic and cinnamic acids, alone or in combination on wheat and some infested weeds comparing with the herbicide isoproturon. Annals of Agric. Sci., Ain Shams Univ. Cairo, v. 52, n. 1, p. 45-58, 2007.

FAYED, T. B; SABRY, S. R. S.; ABOUL-ELA, S. H. Effect of wild oat (Avena fatua), herbicides on weed density, wheat grain yields, and yield components. Annals of Agricultural Science, Cairo, v. 43, n. 1, p. 173-188, 1998.

FLORENTINE, S. K; FOX, E. D. Allelopathic effects of Eucalyptus victrix L. on Eucalyptus species and grasses. Allelopathy J., v. 11, p. 77-84, 2003

GROSS, E. Allelopathy in benthic and littoral area case studies on allelochemicals from benthic cyanobacteria and submerged macrophytes. In: INDERJT; K. M.; DAKSHINI M.; FOY, C. L. (Eds.). Principles and practices in plant ecology allelochemical interactions. Boca Raton: CRC Press, 1999. p. 179-199.

HERBERT, D; PHIPPS, P. J; STRANGE, R. E. Determination of total carbohydrate. Methods in Microbiology 5B, 1971, p. 209-344.

HOPKINS, W. G. Introduction to plant physiology. 2.ed. New York: John Wiley \& Sons., 1999. 512 p.

HUSSEIN, H. F. Estimation of critical period of crop-weed competition and nutrient removal by weeds in onion (Allium cepa L.) in sandy soil. Egypt. J. Agron., v. 24, p. 43-62, 2001.

JANA, B. K. Cultural Requirements of Hippeastrum. In: CHADHA, K. L.; BHATTACHARJEE S. K. (Eds.). Advances in horticulture, v. 12 - Ornamental plants. New Delhi: Malhotra Publishing House,1995.

KAWAGUCHI, S. et al. Effects of aqueous extract of rice plants (Oryza sativa L.) on seed germination and radicle elongation of Monochoria vaginalis var. plantaginea. Plant Growth Regul., v. 23, p. 183-189, 1997.

KUMAR, D. et al. Influence of integrated weed management practices on weed competition for nutrients in wheat. Indian J. Agric. Res., v. 39, n. 2, p. 110-115, 2005.

LAMBERS, H; CHAPIN, F. S; PONS, T. L. Plant physiol. Eco. Springer-Verlag, Berlin., 1998. C. F. Plant Breeding, v. 121, p. $1-9,2002$.

LISANEWORK, N; MICHELSEN, A. Allelopathy in agroforestry systems, the effects of leaf extracts of cupressus lusitanica and three Eucalyptus spp. on four Ethiopian crops. Agroforestry systems, v. 21, p. 63-74, 1993.
MAY, F. E.; ASH, J. E. An assessment of the allelopathic potential of Eucalyptus. Aust. J. Botany, v. 38, n. 3, p. 245-254, 1990.

MEEROW, A. W. et al. The New Phylogeny of the Amaryllidaceae. Herbertia, v. 54, p. 180-203, 2000.

MONTOGOMERY, R. Further studies of the phenolsulphuric acid reagent for carbohydrate. Biochem. Bioph. Acta, p. 48-59, 1961.

MULLER, C. H. Allelopathy as a factor in ecological process Vegetatio, v. 18, p. 348-357, 1969.

NAVAREZ, D.; OLOFSDOTTER, M. Relay seeding technique for screening allelopathic rice (Oryza sativa). Proc. 2nd Int. Weed Control Congr., Copenhagen, 1996, p. $1285-1290$.

NEMAT ALLA, M. M; YOUNIS, M. E. Herbicide effects on phenolic metabolism in maize (Zea mays L.) and soybean (Glycine max L.) seedlings. J. Exp. Bot., v. 46, n. 292, p. 1731-1736, 1995.

NISHIRNURA, H; KAKU, K; NAKAMURA, T; FUKAWAZA, V; MIZUTANI, J. Allelopathic substances, ( $\mu$ )-D-methene-3, 8 diols isolated from Eucalyptus citriodora. Hook. Agric. Biol. Chem., v. 46, p. 319-320, 1982.

OKUBO, H. Hippeastrum (Amaryllis). In: The physiology of flower bulbs. Hertogh A. DE Nard LE (Eds.). Elsevier, 1993, p. 321-324.

OLOFSDOTTER, M; JENSEN, L. B; COURTOIS, B.Improving crop competitive ability using allelopathy - an example from rice. Plant Breeding, v. 121, p. 1-9, 2002

RICE, E. L. In allelopathy. 2.ed. Orlando, FL.: Academic Press, 1984, p. 422.

SHILLING, D. G. et al. Allelopathic potential of celery residue on lettuce. J. Amer. Soc. Hort. Sci., v. 117, p. 308-312, 1992.

SHIMING, L. Allelopathy in South China agroecosystems. The Fourth World Congress in Allelo-pathy, 2005. Charles Sturt Univ. (CSU), Wagga Wagga, NSW Australia from 21-26 August, 2005. p. 8-10.

SIDDIQUE, M. N. A. et al. Effects of twin scale size and hormones on in vitro propagation of hippeastrum (Hippeastrum hybridum). Plant Tissue Cult. \& Biotech., v. 16, n. 2, p. 105-110, 2006

SIDDIQUE, M. N. A; SULTANA, J; SULTANA, N; HOSSAIN, M. M. Effect of planting dates on growth and flowering of Hippeastrum (Hippeastrum hybridum). Int. J. Sustain. Crop Prod., v. 2, p. 12-14, 2007. 
SINGH, S; MALIK, R. K; SANGWAN, N; TAMAK, J. C. Performance of tralkoxydim and isoproturon against

Phalaris minor in wheat. Agric. Sci. Digest Karnal, v. 15, n. 3 , p. $53-155,1995$

SNEDECOR, G. W; COCHRAN, W. G. Statistical methods. 7.ed. Ames: The Iowa State University Press, 1980. 507 p.
SNELL, F. D.; SNELL, C. T. Colorimetric methods. Toronto, New York, London: Organic, D. Van Nostrand Company, 1953. v.3. $606 \mathrm{p}$

WETTSTEIN, D. Chlorophyll lethal und der submikroskopiche Formwechsel der plastiden. Espt. Cell. Res., v. 12, n. 3, p. 427-433, 1957. 